\title{
AKIBAT PELANGGARAN OLEH NOTARIS TERHADAP PEMBUATAN AKTA NOTARIIL
}

\author{
Lorika Cahaya Intan \\ Magister Kenotariatan Fakultas Hukum Universitas Brawijaya \\ Jl. MT. Haryono No. 169 Malang \\ lorikacahayaintan@gmail.com
}

\begin{abstract}
The problem that will be discussed in this research is whether the deed made before the notary is legally valid, in case of violation of Article 16 Paragraph (1) Letter (a) of Notary Position Law, how the Notary's responsibility to the deed already issued by a notary if it does not implement Article 16 Paragraph (1) Subparagraph (a) of the Notary Position Law. The research method used is normative. Based on the result of research in the validity of the deed made before the notary in case of violation of Article 16 Paragraph (1) Subparagraph (a) of Law on Notary Position, as the case of transition or sale and purchase of building on Malang City Government land. Found a deed made before a notary, and has been issued by a notary, in case of violation of Article 16 Paragraph (1) Letter (a) Law on the position of Notary, legally valid. Sanctions only affect the legal subject of a Notary pursuant to Article 16 paragraph (11) that is subject to sanctions in the form of written warning, suspension, dismissal with respect; or dismissal with disrespect.
\end{abstract}

Keywords: Notary, Responsibility, Authentic Deed.

\begin{abstract}
ABSTRAK
Permasalahan yang akan menjadi pembahasan pada penelitian ini yaitu apakah akta yang dibuat di hadapan notaris sah secara hukum, jika terjadi pelanggaran terhadap Pasal 16 Ayat (1) Huruf (a) Undang-Undang Jabatan Notaris, bagaimana tanggung jawab Notaris terhadap akta yang sudah dikeluarkan notaris jika tidak melaksanakan Pasal 16 Ayat (1) Huruf(a) Undang-Undang Jabatan Notaris. Metode penelitian yang digunakan yaitu normatif. Berdasarkan hasil penelitian dalam keabsahan akta yang dibuat di hadapan notaris jika terjadi pelanggaran terhadap Pasal 16 Ayat (1) Huruf (a) Undang-Undang tentang Jabatan Notaris, sebagaimana kasus peralihan atau jual beli bangunan di atas tanah Pemerintah Kota Malang. Ditemukan akta yang dibuat di hadapan notaris, dan sudah dikeluarkan oleh notaris, jika terjadi pelanggaran terhadap Pasal 16 Ayat (1) Huruf(a) Undang-Undang tentang jabatan Notaris, sah secara hukum. Sanksi hanya berpengaruh pada subjek hukum seorang Notaris sesuai pada ketentuan pasal 16 ayat (11) yaitu dapat dikenai sanksi berupa peringatan tertulis, pemberhentian sementara, pemberhentian dengan hormat; atau pemberhentian dengan tidak hormat.
\end{abstract}

Kata Kunci: Notaris, Tanggung jawab, Akta Otentik. 
Lembaga Kenotariatan adalah salah satu lembaga kemasyarakatan yang ada di Indonesia, lembaga ini timbul dari kebutuhan dalam pergaulan sesama manusia yang menginginkan pembuktian dalam melakukan hubungan hukum di bidang keperdataan yang terjadi di antara mereka (G.H.S. Lumban Tobing, 1999, 2). Pemberian kualifikasi notaris sebagai Pejabat Umum berkaitan dengan kewajiban seorang notaris untuk melaksanakan sebagaimana yang termuat dalam Pasal 16 ayat (1) huruf (a) Undang-Undang Jabatan Notaris (UUJN), bertindak amanah, jujur, saksama, mandiri, tidak berpihak, dan menjaga kepentingan pihak yang terkait dalam perbuatan hukum".

Bertindak jujur artinya, seorang notaris diwajibkan oleh undang-undang dalam melakukan profesinya yaitu harus jujur dalam menuangkan isi akta, menyampaikan apa adanya kepada para pihak dalam melakukan perbuatan hukum, selanjutnya yaitu saksama, artinya, sebelum membuat akta yang diminta oleh para pihak terlebih dahulu seorang notaris harus memastikan para pihak benar-benar sesuai dengan identitas yang ditunjukkan dan jangan sampai salah dalam memasukkan data dalam akta, seorang notaris dalam mejalankan profesinya mandiri dan tidak tergantung dengan instansi lain, dan tidak berpihak kepada pihak tertentu.

Pasal 16 Ayat (1) Huruf (a) Undang-Undang Nomor 2 Tahun 2014 tentang tentang Jabatan Notaris (UUJN), jika tidak melaksanakan pasal tersebut akan berakibat terhadap kesempurnaan akta tersebut. Substansi Pasal 16 Ayat (1) UndangUndang Nomor 2 Tahun 2014 tentang Jabatan Notaris berkaitan dengan keterangan dari pihak pembeli bangunan di atas tanah Pemerintah Kota Malang dengan menggunakan jasa notaris di Kota Malang, menjelaskan bahwa terdapat suatu kejanggalan terhadap akta yang dibuatnya, fakta dilapangan dengan apa yang dituangkan dalam akta, sehingga pernyataan atau keterangan para pihak tersebut oleh Notaris dituangkan dalam akta Notaris.
Realitas hukum yang terjadi tersebut menjadi suatu pelajaran tentang kedudukan atau posisi notaris dalam menjadi pejabat umum untuk menuangkan kesepakatan dalam sebuah akta. Berkaitan dengan penjelasan atas Undang-Undang Nomor 2 Tahun 2014 tentang Jabatan Notaris, bahwa karena tindakan ketidakjujuran seorang notaris dalam melaksanakan tugasnya yaitu berakibat fatal terhadap produk hukum yang dibuatnya, yaitu seperti yang tercantum dalam Pasal 16 Ayat (1) Huruf (a) Undang-Undang Nomor 2 Tahun 2014 tentang Jabatan Notaris.

Peralihan atau jual beli bangunan yang berdiri di atas tanah Pemerintah Kota Malang berdasarkan Surat Keputusan Kepala Dinas Perumahan Kota Malang Nomor: 030.2/135/35.73/305/ 2011, yaitu tentang ijin pemakaian tempat-tempat tertentu yang dikuasai oleh Pemerintah Kota Malang tertanggal 11-08-2011, yang dikeluarkan oleh Kepala Dinas Perumahan Kota Malang, dari pihak satu kepada pihak lain yang dikuatkan dengan adanya akta jual beli bangunan dengan Notaris A, Pemerintah Kota Malang yang dikelola oleh Badan Pengelola Aset Daerah (BPAD) tidak bisa berbuat apa-apa mengenai status jual beli yang dilakukan pihak sebelumnya.

Proses peralihan yang tercantum dalam akta jual beli bangunan di atas tanah Pemerintah Kota Malang tidak terdaftar di kantor Badan Pengelola Asset Daerah (BPAD) setempat, yaitu selaku pengelola asset daerah, sehingga pihak pembeli sampai saat ini tidak mendapatkan kepastian hukum selaku pemilik baru berdasarkan AJB tersebut. Indikasi Penyalahgunaan kewenangan yang dilakukan oleh notaris dalam melakukan dan membantu proses peralihan hak sewa atas tanah kepada pihak pembeli mengakibatkan ketidakpastian kepada para pihak. Hal ini dibuktikan dengan tidak terdaftarnya pemilik (Pembeli) sebagai pemilik hak sewa atas tanah tersebut di atas tanah Pemerintah Kota Malang. Pokok permasalahan yang akan menjadi pembahasan pada penelitian ini yaitu apakah akta yang dibuat di hadapan nota- 
ris sah secara hukum, jika terjadi pelanggaran terhadap Pasal 16 Ayat (1) Huruf (a) Undang Nomor 2 Tahun 2014 tentang Jabatan Notaris. Tanggung jawab Notaris terhadap akta yang sudah dikeluarkan notaris jika tidak melaksanakan Pasal 16 Ayat (1) Huruf (a) Undang-Undang Nomor 2 Tahun 2014 tentang Jabatan Notaris.

\section{Pembahasan}

Proses peralihan yang tercantum dalam akta jual beli bangunan di atas tanah Pemerintah Kota Malang tidak terdaftar di kantor Badan Pengelola Asset Daerah (BPAD) setempat, oleh karena itu pihak pembeli sampai saat ini tidak mendapatkan kepastian hukum selaku pemilik baru berdasarkan AJB tersebut. Berdasarkan keterangan pihak pembeli, bahwa di saat proses peralihan hak bangunan dari pihak pertama kepada pihak kedua, Notaris tidak membacakan isi akta jual beli tersebut kepada pembeli, akhirnya isi akta tidak sama dengan fakta dilapangan.

Keabsahan Akta yang dibuat di Hadapan Notaris jika terjadi pelanggaran terhadap Pasal 16 Ayat (1) Huruf (a) Undang-Undang Nomor 2 Tahun 2014 tentang Perubahan Undang-Undang Nomor 30 Tahun 2004 tentang Jabatan Notaris. G.H.S. Lumban Tobing, dalam bukunya yang berjudul Peraturan Jabatan Notaris menyebutkan bahwa lembaga kemasyarakatan yang dikenal sebagai "notaris" ini timbul dari kebutuhan dalam pergaulan sesama manusia, yang menghendaki adanya alat bukti baginya mengenai hubungan hukum keperdataan yang ada dan/ atau terjadi diantara mereka, suatu lembaga dengan pengabdiannya yang ditugaskan oleh kekuasaan umum (openbaar gezag) untuk dimana dan apabila undangundang mengharuskan sedemikian atau dikehendaki oleh masyarakat, membuat alat bukti tertulis yang mempunyai kekuatan otentik.

Pasal 1338 KUHPerdata adalah pilar utama asas kebebasan berkontrak, artinya bebas tidak dalam arti sebenarnya, tapi bebas ada pembatasan atau perkecualian. Menurut pendapat umum yang di anut pada setiap akta otentik demikian juga pada akta notaris mempunyai 3 (tiga) kekuatan pembuktian yaitu (G.H.S. Lumban Tobing, 1999, 55-59):

Kekuatan pembuktian lahiriah (Uitwendige bewijs kracht) akta otentik merupakan kemampuan akta itu sendiri untuk membuktikan keabsahan sebagai akta otentik "acta publica probant sesse ipsa" jika dilihat dari luar atau lahirnya sebagai akta otentik serta sesuai dengan aturan hukum yang sudah ditentukan mengenai syarat akta otentik maka akta tersebut berlaku sebagai akta otentik sampai terbukti sebaliknya artinya sampai ada yang membuktikan bahwa akta tersebut bukan akta otentik secara lahiriah (Sudikno Mertokusumo, 1999, 123).

Nilai pembuktian akta notaris dari aspek lahiriah, akta tersebut harus dilihat apa adanya, secara lahiriah tidak perlu dipertentangkan dengan alat bukti yang lain. Jika ada yang menilai bahwa suatu akta notaris tidak memenuhi syarat sebagai akta otentik, maka yang bersangkutan wajib membuktikan bahwa akta tersebut secara lahiriah bukan akta otentik.

Kekuatan pembuktian formil (Formale Bewijskracht) akta notaris harus memberikan kepastian bahwa suatu kejadian dan fakta tersebut dalam akta betul-betul dilakukan oleh Notaris atau diterangkan oleh pihak-pihak yang menghadap pada saat yang tercantum dalam akta sesuai dengan prosedur yang sudah ditentukan dalam pembuktian akta. Secara formal untuk membuktikan kebenaran dan kepastian tentang hari, tanggal, bulan, tahun, pukul atau waktu menghadap. identitas dari para pihak menghadap comparanten, paraf dan tanda tangan para pihak yang penghadap, saksi dan Notaris, demikian juga tempat dimana akta itu dibuat, serta akta pejabat/ berita penghadap pada akta pihak.

Berdasarkan teori kepastian hukum, kepastian hukum mengharuskan dilahirkannya kaedah-kaedah yang berlaku secara umum agar ter- 
cipta suasana yang aman dan tentram dalam masyarakat. Apabila aspek formal dipermasalahkan oleh para pihak, maka harus dibuktikan oleh formalitas dari akta, yaitu harus dapat membuktikan ketidakbenaran mereka yang menghadap, pembuktian ketidakbenaran tempat dimana akta itu dibuat, pembuktian ketidakbenaran apa yang dilihat, disaksikan dan didengar oleh Notaris, dan juga harus dapat membuktikan ketidakbenaran pernyataan atau ketidakbenaran para pihak yang diberikan atau disampaikan di hadapan notaris, dan ketidakbenaran tanda tangan para pihak, saksi dan Notaris atau ada prosedur pembuatan akta yang tidak dilakukan.

Dengan kata lain pihak yang mempermasalahkan akta tersebut harus melakukan pembuktian terbalik untuk menyangkal aspek formal dari akta Notaris. Jika tidak mampu membuktikan ketidakbenaran tersebut, maka akta tersebut harus diterima oleh siapapun. Pengingkaran atau penyangkalan harus dilakukan dengan suatu gugatan kepengadilan umum. Penggungat harus dapat membuktikan bahwa ada aspek formal yang dilanggar atau tidak sesuai dalam akta yang bersangkutan misalnya bahwa yang bersangkutan tidak pernah merasa menghadap Notaris pada hari, tanggal, bulan tahun, dan pukul yang tersebut dalam awal akta atau merasa tanda tangan dirinya, demikian juga tempat dimana akta itu dibuat tidak sama dalam penutup akta.

Kekuatan pembuktian material (Materiele bewijskracht) merupakan kepastian tentang materi suatu akta, karena apa yang tersebut dalam akta merupakan pembuktian yang sah terhadap pihakpihak yang membuat akta atau mereka yang mendapatkan hak dan berlaku untuk umum, kecuali ada pembuktian sebaliknya, keterangan atau pernyataan yang dituangkan/ dimuat dalam akta pejabat atau akta berita acara atau keterangan para pihak yang disampaikan di hadapan Notaris dan para pihak harus dinilai benar berkata yang kemudian dituangkan dalam akta.
Ketiga aspek di atas merupakan kesempurnaan Akta Notaris sebagai akta otentik dan siapapun terikat oleh akta tersebut. Jika dapat dibuktikan dalam suatu persidangan pengadilan, bahwa ada salah satu aspek tersebut tidak benar, maka akta bersangkutan hanya mempunyai kekuatan pembuktian akta di bawah tangan atau akta tersebut didegradasikan dalam kekuatan pembuktiannya sebagai akta yang mempunyai kekuatan pembuktian sebagai akta di bawah tangan.

\section{Keabsahan Akta}

Analisis terhadap keabsahan Akta yang dibuat di hadapan Notaris jika terjadi pelanggaran terhadap Pasal 16 Ayat (1) Huruf (l) UndangUndang Nomor 2 Tahun 2014 tentang Jabatan Notaris (UUJN), ditegaskan bahwa; "Dalam menjalankan jabatannya Notaris berkewajiban membacakan akta di hadapan penghadap dengan dihadiri oleh paling sedikit dua orang saksi dan ditandatangani pada saat itu juga oleh penghadap, saksi, dan Notaris". Apabila syarat formal dalam pembuatan akta tidak dipenuhi, maka akta yang dibuat oleh Notaris hanya mempunyai kekuatan pembuktian sebagai akta di bawah tangan.

Suatu aspek materiil ataupun formil dalam sebuah akta sangat penting untuk mengukur terhadap keabsahan akta tersebut, sehingga advice yang diberikan oleh seorang Notaris bisa menjamin terhadap perjanjian yang dilakukan oleh para pihak. Hal ini secara normatif mengkaitkan dengan teori kepastian hukum sebagaimana yang dikutip dalam pendapat Peter Mahmud Marzuki, bahwa teori kepastian hukum mengandung 2 (dua) pengertian yaitu:

Pertama, adanya aturan jelas yang memberikan pemahaman kepada seseorang untuk melakukan atau tidak melakukan suatu perbuatan tertentu. Artinya dalam hal ini suatu degradasi sebuah Akta yang dibuat oleh Notaris sebagaimana yang terdapat dalam Pasal 16 Ayat (1) Huruf 1 dan Ayat 
(7) Undang-Undang Nomor 2 tahun 2014 tentang Jabatan Notaris tidak terpenuhi, akta yang bersangkutan hanya mempunyai kekuatan pembuktian sebagai akta di bawah tangan. Namun dalam pasal tersebut tidak dijelaskan mengenai degradasi Akta Notaris jika tidak melaksanakan Pasal 16 Ayat (1) Huruf (a) UUJN. Padahal dalam pasal tersebut seorang Notaris wajib bertindak amanah, jujur, saksama, mandiri, tidak berpihak, dan menjaga kepentingan pihak yang terkait dalam perbuatan hukum;

Kedua, dengan adanya aturan hukum yang bersifat umum, setiap warga negara dapat mengetahui apa saja beban tanggung jawab yang dapat dijatuhkan oleh Negara kepadanya dan untuk membebaskan setiap warga negara dari kesewenang-wenangan negara dalam menjatuhkan hukuman. Kepastian hukum bukan hanya berupa pasal-pasal dalam undang-undang melainkan juga adanya konsistensi dalam putusan Hakim antara putusan hakim yang satu dengan putusan hakim lainnya untuk kasus yang serupa yang telah di putuskan (Marzuki, 2008, 158).

Notaris dalam hal ini diberi wewenang untuk menuangkan semua perbuatan sebagaimana yang tercantum dalam Pasal 1 Undang-Undang Nomor 2 Tahun 2014 tentang Jabatan Notaris, "Notaris adalah pejabat umum yang berwenang untuk membuat akta otentik dan memiliki kewenangan lainnya sebagaimana dimaksud dalam undang-undang ini atau berdasarkan undangundang lainnya". Sebagaimana yang tercantum dalam Pasal 16 Ayat (1) Huruf (a) UUJN, bahwa jika seorang Notaris tidak melaksanakan pasal tersebut di atas maka dapat dikenakan sanksi berupa peringatan tertulis, pemberhentian sementara, pemberhentian dengan hormat, atau pemberhentian dengan tidak hormat.

\section{Degradasi Bukti dan Batalnya Akta Notaris}

Mengenai faktor-faktor penyebab terdegradasinya Akta Notaris sebagai alat bukti yang kuat dan terpenuh, serta batalnya akta Notaris, pada dasarnya dapat disebabkan oleh beberapa hal. Salah satu diantaranya diatur dalam ketentuan pasal 1868 KUHPerdata yang dirumuskan; "Akta otentik adalah akta yang didalam bentuk yang ditentukan oleh undang-undang dibuat oleh dan dihadapan pejabat umum yang berwenang untuk itu ditempat dimana akta itu dibuat".

Pasal ini hanya merumuskan arti kata otentik dan tidak menyebutkan siapa pejabat umum itu, bagaimana bentuk aktanya dan kapan pejabat umum itu berwenang, secara implicit pasal 1868 KUHPerdata menghendaki adanya undangundang yang mengatur tentang pejabat umum dan bentuk aktanya. Undang-undang Nomor 2 Tahun 2014 tentang Jabatan Notaris merupakan satusatunya Undang-Undang organik yang mengatur Notaris sebagai pejabat umum dan bentuk akta Notaris.

\section{Tanggung Jawab Notaris Terhadap Akta}

\section{a. Tanggungjawab Notaris Terhadap Gugatan Perdata}

Apabila mengacu pada konsep "liability" dan

"responsibility" di atas, dilihat dari cakupan maknanya berarti keduanya memiliki perbedaan. Istilah "liability" berarti suatu keadaan untuk melaksanakan kewajiban hukum tertentu. Sedangkan istilah "responsibility" memiliki makna yang lebih luas, karena tidak hanya berupa kewajiban (obligation) untuk merespon atau memenuhi atas apa yang pernah dilakukan terkait dengan keputusan, keahlian, dan kemampuan seseorang, tetapi juga kewajiban untuk memulihkan (restitution) atau membayar ganti rugi terhadap kerugian yang disebabkan oleh tindakan yang pernah dilakukan. Ini berarti bahwa istilah "responsibility" mencakup tidak hanya kewajiban untuk memenuhi atau memikul tanggung jawab hukum tetapi juga tanggung jawab moral terkait dengan tindakan, keputusan, keahlian (profesi) tertentu yang sedang dilakukan. Dengan demikian, berarti istilah "tang- 
gung jawab" baik dalam arti "liability" dan "responsibility" tidak bisa dilepaskan dari makna kewajiban (obligation).

Hakikatnya tugas dan kewenangan notaris adalah mengkonstantir keinginan atau kehendak yang diterangkan oleh penghadap kedalam sebuah akta otentik dengan mendasarkan pembuatannya pada ketentuan perundang-undangan yang berlaku. Hal ini dikuatkan dengan Putusan Mahkamah Agung Nomor: 702 K/Sip/1973 tertanggal 5 September 1973 yang berbunyi: Notaris fungsinya hanya mencatatkan/ menuliskan apa-apa yang dikehendaki dan dikemukan oleh para pihak yang menghadap notaris tersebut. Tidak ada kewajiban bagi notaris untuk menyelidiki secara materil apaapa (hal-hal) yang dikemukakan oleh penghadap dihadapan notaris tersebut.

Berkaitan dengan gugatan perdata yang ada hubungannya dengan akta otentik yang telah dibuat oleh dan/ di hadapan notaris, terdapat dua kemungkinan kedudukan notaris dalam gugatan perdata tersebut, yang diantaranya (Habib Adjie, 2009, 21):

1. Notaris dipanggil dalam kapasitasnya sebagai saksi di pengadilan terkait dengan akta yang telah dibuat dihadapan atau oleh dirinya yang dijadikan sebagai alat bukti dalam perkara perdata.

2. Notaris dipanggil dalam kapasitasnya sebagai tergugat yang dilayangkan di pengadilan terkait akta otentik yang dibuatnya karena dianggap telah merugikan pihak penggugat.

Pembuktian perdata, suatu akta otentik yang dibuat dihadapan atau oleh notaris merupakan alat bukti yang sempurna bagi pihak yang berkepentingan. Hal terjadinya penyangkalan bahwa pihak yang menyangkalnya harus bisa membuktikan ketidakbenaran akta tersebut mengenai kepastian:

1. Hari, tanggal, bulan dan tahun penghadap.

2. Waktu (pukul) menghadap.
3. Tanda tangan yang tercantum dalam minuta akta.

4. Merasa tidak pernah menghadap.

5. Akta tidak ditanda tangani dihadapan notaris.

6. Akta tidak dibacakan.

7. Alasan lain berdasarkan formalitas akta.

Penyangkalan terhadap hal-hal yang disebut di atas dapat dilakukan dengan cara mengajukan gugatan ke pengadilan negeri oleh pihak yang mempermasalahkan keotentikan akta notaris tersebut. Jika gugatan mengenai ketidakbenaran akta yang dibuat notaris itu tidak terbukti di muka persidangan, maka akta notaris tersebut tetap berlaku sebagai alat bukti yang bernilai sempurna dan mengikat para pihak-pihak yang berkepentingan terhadapnya sepanjang tidak dibatalkan oleh para pihak sendiri atau berdasarkan putusan pengadilan. Namun jika gugatan untuk menyangkal ketidakbenaran akta tersebut terbukti, maka kedudukan akta notaris tersebut akan terdegradasi menjadi akta di bawah tangan dimana nilai pembuktiannya akan tergantung pada pihak atau hakim yang menilainya.

Berdasarkan pendapat Habib Adjie, terdegradasinya akta notaris menjadi akta di bawah tangan yang berdampak pada kerugian materiil yang dialami oleh pihak yang menggugat dan pihak tersebut dapat membuktikan mengenai kerugian yang dialaminya, maka penggugat tersebut dapat meminta sejumlah ganti kerugian (E.Y Kanter dan S.R Sianturi, 1982, 166).

\section{b. Tanggungjawab notaris terhadap gugatan pidana}

Definisi kesalahan secara umum dapat ditemukan dalam bidang hukum pidana. Hukum pidana, seseorang yang dinyatakan bersalah harus memenuhi unsur-unsur sebagai berikut: (Habib Adjie, 2009, 22)

1. Mampu bertanggung jawab;

2. Sengaja atau alpa;

3. Tidak ada alasan pemaaf 
Kemampuan bertanggung jawab merupakan keadaan normalitas psikis dan kematangan atau kecerdasan seseorang yang membawa kepada tiga kemampuan yaitu:

a. Mampu untuk mengerti nilai dan akibat-akibatnya sendiri;

b. Mampu untuk menyadari bahwa perbuatan itu menurut pandangan masyarakat tidak diperbolehkan;

c. Mampu untuk menentukan niat dalam melakukan perbuatan itu.

Permasalahan pertama menyangkut apakah Notaris dalam hal membuat akta otentik mengerti benar akan nilai dan akibat-akibat dari pembuatan akta tersebut, sebelum akhirnya akta tersebut dinyatakan cacat hukum, dalam praktek lebih banyak ditemui seseorang Notaris yang akan membuat akta cenderung menganggap akta yang dibuat sudah sah apabila para pihak telah sepakat, dan masing-masing pihak cakap melakukan perbuatan hukum, ada objek dan causa yang diperbolehkan.

Notaris juga memiliki peran dalam hal memberikan nasehat hukum kepada penghadap terkait permasalahan yang ada, yang kemudian juga diformulasikan sebagai bagian dari keinginan dari penghadap yang dituangkan ke dalam akta otentik dan bukan sebagai keinginan notaris yang dituangkan dalam akta.

Memidanakan notaris berdasarkan aspekaspek formal semata tanpa mengkaji lebih dalam mengenai unsur kesalahan ataupun kesengajaan dari notaris merupakan suatu perbuatan tindakan tanpa dasar hukum yang tidak dapat dipertanggungjawabkan. Misalnya: (Habib Adjie, 2008, 122123)

1. Dalam hal Notaris dituduh telah membuat surat palsu atau memalsukan surat yang seolah-olah surat tersebut adalah surat yang asli dan tidak dipalsukan (Pasal 263 ayat 1 KUHP), melakukan pemalsuan surat, dan pemalsuan tersebut telah dilakukan didalam akta-akta otentik (Pasal 264 ayat 1 angka 1 KUHP) mencantumkan suatu keterangan palsu didalam suatu akta otentik (Pasal 266 ayat 1 KUHP). Hal yang perlu diketahui bahwa notaris tidak membuat surat akan tetapi notaris membuat akta, sehingga perlu dibedakan antara akta dengan surat. Surat mengandung makna alat bukti yang dibuat dan dipergunakan untuk maksud dan tujuan tertentu tanpa terikat pada prosedur tertentu yang diatur dalam undangundang. Hal ini tentu berbeda dengan definisi akta yang bermakna alat bukti yang sejak semula dibuatnya digunakan sebagai alat bukti yang bernilai sempurna untuk maksud dan tujuan tertentu dihadapan atau oleh pejabat yang berwenang dengan mengacu pada prosedur pembuatan yang diatur dalam peraturan perundang-undangan. Dalam kaitannya dengan pasal 263 ayat 1 KUHP bahwa akta notaris tidak bisa serta merta dipersamakan dengan surat pada umumnya karena dari kaedah pembuatannya yang berbeda.

2. Pada dasarnya setiap keterangan atau pernyataan yang diterangkan penghadap kepada notaris merupakan bahan utama dalam pembuatan akta otentik sesuai dengan keinginan dan kehendak pihak yang menghadap. Karena tanpa adanya kehendak atau keinginan yang diterangkan penghadap kepada notaris, mustahil notaris dapat membuat akta. Jikalau ada keterangan ataupun pernyataan yang diduga palsu yang kemudian dimasukkan atau dicantumkan ke dalam akta notaris tidak lantas menjadikan akta tersebut menjadi palsu. Contohnya dalam pembuatan akta, pihak penghadap menyerahkan KTP atau Surat Nikah yang secara fisik terlihat asli untuk dimasukkan sebagai keterangan perihal identitas penghadap di dalam akta. Jika dikemudian hari terbukti ternyata surat nikah atau KTP tersebut adalah palsu bukan berarti notaris telah memasukkan keterangan palsu ke dalam 
akta sebagaimana yang dimaksud pasal 264 ayat 1 angka 1 KUHP dan Pasal 266 ayat 1 KUHP, akan tetapi hal tersebut menjadi tanggung jawab pihak yang menghadap sendiri karena tidak ada kewajiban bagi notaris untuk meneliti lebih dalam mengenai maksud dan tujuan penghadap membuat akta.

Penjatuhan sanksi perlu diperhatian mengenai sifat, sasaran dan prosedur penerapan sanksisanksi tersebut karena penjatuhan sanksi perdata, sanksi administratif dan sanksi pidana memiliki sifat, sasaran dan prosedur yang berbeda. Sanksi perdata dan administratif sasarannya lebih menekankan pada penjatuhan hukuman terhadap perbuatan hukum yang dilakukan sedangkan sanksi pidana sasarannya lebih menekankan pada orang yang melakukan perbuatan melawan hukum.

Sanksi administratif dan sanksi perdata bersifat reparatoir atau korektif yang artinya memperbaiki suatu keadaan yang agar perbuatan tersebut tidak dilakukan kembali oleh notaris yang bersangkutan atau oleh notaris lain. Bersifat regresif yang artinya memulihkan kembali suatu keadaan agar seperti sebelum terjadinya pelanggaran. Aturan hukum tertentu selain dijatuhi hukum adinistratif juga dijatuhi hukuman secara pidana secara kumulatif yang bersifat condemnatoir atau menghukum. Kaitannya dengan pelanggaran undang-undang jabatan notaris perubahan tidak diatur mengenai sanksi pidana dalam undang-undang tersebut sehingga dalam hal ini sanksi pidana didasarkan pada ketentuan pidana umum. (Habib Adjie, 2008, 124).

Kriteria yang menjadi batasan-batasan dapat dipidananya seorang notaris adalah sebagai berikut: (Habib Adjie, 2008, 127)

1. Apabila dengan sengaja dan penuh kesadaran seorang notaris turut serta bersama-sama dengan salah satu pihak untuk melakukan tindakan hukum terhadap aspek formal akta yang dibuat dihadapan atau oleh notaris demi menguntungkan salah satu pihak dan merugikan pihak yang lain.

2. Apabila akta yang dibuat dihadapan atau oleh notaris dapat dibuktikan bahwa dalam pembuatannya tidak berdasar atau bertentangan dengan undang-undang jabatan notaris perubahan.

3. Apabila majelis pengawas menilai bahwa tindakan hukum yang dilakukan notaris dalam menjalankan jabatannya tidak sesuai dengan ketentuan yang mengatur profesi notaris.

Sepanjang tindakan hukum yang dilakukan notaris telah memenuhi kriteria di atas maka notaris yang bersangkutan dapat dipidanakan karena dianggap telah memenuhi unsur-unsur pelanggaran yang terdapat tidak hanya pada UUJN tetapi juga harus berdasar kriteria pelanggaran yang menjadi batasan dalam kode etik profesi notaris dan juga ketentuan dalam Kitab Undang-Undang Hukum Pidana. Tidak dibenarkan memidanakan notaris dengan hanya berpegang pada ketentuan pelanggaran yang terdapat dalam KUHP semata, karena hal tersebut merupakan bentuk kesalahan dalam memahami kedudukan notaris sebagai jabatan.

\section{c. Perbuatan Melanggar Hukum yang Dilakukan oleh Notaris}

Perbuatan melanggar hukum merupakan perbuatan yang menimbulkan kerugian, dan secara normatif perbuatan tersebut tunduk pada ketentuan pasal 1365 KUHPerdata. Bentuk tanggung gugat yang dianut oleh pasal 1365 KUHPerdata ini adalah tanggung gugat berdasarkan kesalahan (Liability based fault). Hal ini dapat dilihat dalam ketentuan pasal tersebut yang mensyaratkan adanya kesalahan pada pelaku untuk sampai pada keputusan apakah perbuatan seseorang itu merupakan perbuatan melanggar hukum. Selain itu perlu dipahami, bahwa unsur kesalahan itu harus dibuktikan oleh pihak yang menderita kerugian 
sebagaimana yang diatur dalam pasal 1865 KUHPerdata dan 163 HIR, dan mengenai ada tidaknya kesalahan Notaris, telah di jelaskan pada pembahasan terdahulu.

Perbuatan melanggar hukum, yang dimaksud dalam perbuatan melanggar hukum oleh Notaris, tidak hanya perbuatan yang langsung melanggar hukum, melainkan juga perbuatan yang secara langsung melanggar peraturan lain. Yang dimaksud dengan peraturan lain adalah peraturan yang berada dalam lapangan kesusilaan, keagamaan dan sopan santun dalam masyarakat dilanggar. Kasus peralihan atau jual beli bangunan di atas tanah pemkot Kota Malang yang dikelola oleh Badan Pengelola Aset Daerah (BPAD), maka terhadap Notaris yang aktanya cacat hukum, maka Notaris yang bersangkutan telah menyalahi ketentuan Pasal 16 Ayat (1) Huruf (a) UUJN, yang dikaitkan dengan Pasal 1865 Jo 1870 KUHPerdata, selain pengertian tentang perbuatan melanggar hukum seperti tersebut di atas.

\section{Penutup}

Berdasarkan hasil pembahasan dan analisis yang dilakukan terdahulu, maka dapat disimpulkan bahwa keabsahan akta yang dibuat di hadapan Notaris jika terjadi pelanggaran terhadap Pasal 16 Ayat (1) Huruf (a) Undang-undang Nomor 2 Tahun 2014 tentang Perubahan Undang-Undang Nomor 30 Tahun 2004 tentang Jabatan Notaris sebagaimana kasus peralihan atau jual beli bangunan di atas tanah Pemerintah Kota Malang, merupakan akta yang sah secara hukum karena telah memenuhi syarat sahnya suatu perjanjian (Pasal 1320 KUHPerdata). Apabila dikaitkan dengan tidak terpenuhinya Pasal 16 Ayat (1) Huruf 1 UU JN, maka akta ini terdegradasi dari akte otentik menjadi akte di bawah tangan. Berdasarkan UU JN, sanksi berpengaruh pada subjek hukum seorang Notaris sebagaimana ketentuan Pasal 16 Ayat (11) yaitu dikenai sanksi berupa; peringatan tertulis, pemberhentian sementara, pemberhentian dengan hormat atau pemberhentian dengan tidak hormat.

Bahwa tanggung jawab Notaris terhadap akta yang sudah dikeluarkan notaris jika tidak melaksanakan Pasal 16 Ayat (1) Huruf (a) UU JN, dalam hal ini diklasifikasikan terdapat 2 (dua) aspek pertanggungjawaban diantaranya pertanggungjawaban perdata, dan pertanggungjawaban secara administratif terhadap Notaris. Atas dasar cacat hukum. Tentang perjanjian yang sudah dituangkan dalam akta, maka langkah yang dilakukan para pihak yang dirugikan bisa melakukan penggantian biaya ganti rugi sebagaimana yang tertuang dalam pasal 1365 KUHPerdata. Hal di atas, kiranya perlu adanya tindakan yang inten dari majelis pengawas daerah terhadap notaris-notaris yang tidak mematuhi kewajiban-kewajiban yang terdapat dalam Undang-Undang Jabatan Notaris dalam memberikan jasa hukum kepada klien. Demikian pula perlu adanya regulasi hukum mengenai tindakan terhadap Notaris yang seringkali melakukan tindakan pelanggaran hukum yang mengakibatkan kerugian pada para pihak.

\section{DAFTAR PUSTAKA}

\section{Buku}

Abdul Qadir, Muhammad, 2011, "Etika Profesi Hukum", Citra Aditya Bakti, Bandung.

Adjie, Habib, 2009, Hukum Notaris Indonesia, Refika Aditama, Bandung.

, 2008, Sanksi Perdata dan Administratif Terhadap Notaris Sebagai Pejabat Publik, Refika Aditama, Bandung.

Budiono, Herlien 2009, Ajaran Umum Hukum Perjanjian dan Penerapannya di Bidang Kenotariatan, Citra Aditya Bakti, Bandung.

Hernoko, Agus Yudha, 2010, Hukum Perjanjian Asas Proporsionalitas dalam Kontrak Nasional, Kencana, Jakarta. 


\section{Akibat Pelanggaran oleh Notaris terhadap Pembuatan Akta Notariil}

Lorika Cahaya Intan

Marzuki, Peter Mahmud, 2005, Penelitian Hukum. Kencana, Jakarta.

Mertokusumo, Sudikno, 1999, Mengenal Hukum Suatu Pengantar, Liberty, Yogyakarta.

Saputro, Anke Dwi, ed., 2008, 100 Tahun Ikatan Notaris Indonesia. Jati Diri Notaris Indonesia. Dulu. Sekarang. dan di Masa Datang, Gramedia Pustaka Utama, Jakarta.

Soekanto, Soerjono, 1981, Fungsi Hukum dan Perubahan Sosial, Alumni, Bandung.

Tobing, G.H.S, Lumban 1980, Peraturan Jabatan Notaris, Erlangga, Jakarta.

Yahanan, Annalisa et. al, 2000, Perjanjian Jual Beli Berklausula Perlindungan Hukum Paten, Tunggal Mandiri Publishing, Malang.

Peraturan Perundang-Undangan

Undang-undang dasar Negara Republik Indonesia UUD 1945
Kitab Undang-Undang Hukum Perdata KUHPerdata (Burgerlij Wetbuk).

Undang-Undang Nomor 2 Tahun 2014 tentang Jabatan Notaris.

Undang-undang Nomor 5 tahun 1960 tentang PokokPokok Agraria Nomor (UUPA)

Peraturan Pemerintah Republik Indonesia Nomor 37 Tahun1998 Tentang Peraturan Jabatan Pejabat Pembuat Akta Tanah

Peraturan Kepala Badan Pertanahan Nasional Republik Indonesia Nomor 1 Tahun 2006 Tentang Ketentuan Pelaksanaan PP No. 37 Tahun 1998

Peraturan Kepala Badan Pertanahan Nasional Republik Indonesia Nomor 23 Tahun 2009 Tentang Perubahan Atas Peraturan Kepala Badan Pertanahan Nasional RI Nomor 1 Tahun 2006

Kode Etik Pejabat Pembuat Akta Tanah

Kode Etik Notaris 